\title{
From Doubt To Its Social Articulation
}

Pragmatist Insights

Mathias Girel

\section{(2) OpenEdition Journals}

Electronic version

URL: http://journals.openedition.org/ejpap/536

DOI: $10.4000 /$ ejpap.536

ISSN: 2036-4091

Publisher

Associazione Pragma

\section{Electronic reference}

Mathias Girel, «From Doubt To Its Social Articulation », European Journal of Pragmatism and American Philosophy [Online], V-2 | 2013, Online since 24 December 2013, connection on 01 May 2019. URL

http://journals.openedition.org/ejpap/536 ; DOI : 10.4000/ejpap.536

This text was automatically generated on 1 May 2019.

\section{(c) $(1) \odot$}

Author retains copyright and grants the European Journal of Pragmatism and American Philosophy right of first publication with the work simultaneously licensed under a Creative Commons AttributionNonCommercial-NoDerivatives 4.0 International License. 


\title{
From Doubt To Its Social Articulation
}

\author{
Pragmatist Insights
}

\section{Mathias Girel}

1 Debunking pathological doubts and sundry variants of skepticism certainly has been one of the most prominent features of Pragmatism since its inception in the early 1870s. Peirce's theory of inquiry and his 1868-69 series, James's The Will to Believe, and Dewey's later The Quest for Certainty - to which the last Wittgenstein, as a non-standard pragmatist, might be added - have offered very different strategies to address this question and to counter skeptical doubts. Extant scholarship already provides substantive accounts of this feature of pragmatism, ${ }^{1}$ and we find in the classical pragmatists several distinct approaches. I will try to show, in this introductory Essay, how and why the social texture of doubt always lurks in the background, and to do so, I will proceed from this classical thesis to the idea that doubt has a genuinely social articulation, which will allow me to exhibit how the following papers all cast light, in different ways, on this very idea.

\section{Several strikes at skepticism}

2 Developing an approach to inquiry where belief and doubt play a major role, as in Peirce's Illustrations of the Logic of science, is one thing while facing skepticism another; but the classical pragmatists, in their critiques of skepticism, have all faced some variants of artificial doubts barring the way of inquiry.

\section{Peirce: Get Rid of those Superfluous Faculties!}

3 As regards Peirce, it is safe to say that skepticism is, to his eyes, as it is often in the tradition, the counterpart of a foundationalism gone astray. ${ }^{2}$ Skepticism is the direct effect of an abstract and foundationalist approach to knowledge: it is naturally and always produced by 
these kinds of philosophies. Peirce opposes artificial doubts in the same way as he opposes foundationalist epistemologies. ${ }^{3}$

4 He goes even further in his first texts, as to say that the very idea of an "unknowable," that is to say of something, a realm or a mode of being, that would radically elude our knowledge, is the prototype of the meaningless ideas that induce skepticism and that should be disposed of in a proper philosophy. His first major paper, in 1868, Some Faculties Claimed for Man, is an examination of the faculties or powers we think we have but we don't, and which are, each one in its own respect, the cornerstones of a bad or a misleading philosophy. For example, the idea of an intuition (that it to say, to put things in a Sellarsian way, of a self-justifying episode giving authority to other epistemic episodes), that of a private realm, of mere thought without signs, are so many cornerstones, and the culmination of Peirce's criticism lies thus with the criticism of the Unknowable, the standpoint of nowhere, of the knowledge that we would have if we were to occupy that standpoint and which would in comparison make of our actual knowledge or phenomenal knowledge a "second best" :

If we can not only have no knowledge of things in themselves as the skeptics and critics maintain, but cannot even conceive of them at all, so the word is simply devoid of meaning, then they do not exist, and consequently we can attain to a knowledge of the very things themselves. So that by simply denying to man one more faculty we restore (practically) to him the most important of those of which he has been stripped by skepticism. ${ }^{4}$

Get rid of this fiction, and you will start restoring in its full extent your access to the things themselves. There is thus an ongoing guerilla to be waged against skepticism. What will become the pragmatist maxim, by helping us dissolving these fictions and focusing of the "practical bearings" of our conceptions to elucidate their meanings, will play an instrumental role in bringing us back to the "very things themselves" (which does not mean bringing us back to mere immediacy of course).

The possibility of skepticism will always resurface, but one enduring parade is to stick to what is aimed through the inquiry (the settlement of belief), and to criticize frivolous attempts, by the "metaphysicians" or by most of us when we are not careful enough, to forget that leading principle.

\section{James and the Opacity of Existence}

7 The problem of skepticism certainly has different faces in James's philosophy but in some of his earliest and most famous lines, there is a Promethean idea that theoretical skepticism will be "cured" by practice.

8 The core of The Will to Believe's essays were written in the late 1870s and early 1880s and were still imbibed with the atmosphere captured by Thomas Carlyle when he spoke of "an age at once destitute of faith and terrified at skepticism" (that is a thought that strongly impressed Stuart Mill, who quotes it in On Liberty ${ }^{5}$ ).

9 Carlyle gives vivid descriptions of a particular mood: that of "speculative melancholy." 6 The crux of his Sartor Resartus is the passing from the "Everlasting no" - romantic nihilism - to the "Everlasting yes," where vivid descriptions of "this romantic state of mind" from which "there is absolutely no possible theoretic escape" are given. In all these cases, as for Teufelsdröckh, Carlyle's philosophical hero: 
The world appears to us potentially as what the same Carlyle once called it, as vast, gloomy, solitary Golgotha and mill of death. The only escape is by the practical way. [...] What was the most important thing [Carlyle] said to us? He said: "Hang your sensibilities! Stop your snivelling complaints, and your equally snivelling raptures! Leave off your general emotional tomfoolery and WORK like men!" But this means a complete rupture with the subjectivist philosophy of things. It says conduct, and not sensibility, is the ultimate fact for our recognition. ${ }^{7}$ quite clear that Carlyle's lesson concerns what philosophy and its limits are about: the "essence of this philosophy of objective conduct" is "the recognition of limits, foreign and opaque to our understanding." As a matter of fact, it is exactly - as in Kant - the acknowledgment of these limits that has decisive practical consequences and that opens a way out of the dialectical mazes.

11 Carlyle had given, still in Sartor Resartus, a description of belief clearly anticipating that of James in The Will to Believe. To know a man, said Carlyle, is to know his convictions, not his mere speculative, or argumentative ones, but those that involve his practice. Carlyle, most often, is thus interested not in the beliefs men profess, but in beliefs their conduct betray, and any reader of The Will to Believe and of The Varieties of Religious Experience can appreciate the close relationship between some of James's ideas and Carlyle's definition of belief, as "the thing a man does practically believe and this is often enough without asserting it even to himself, much less to the others."

We see men of all kind of professed creeds attain to almost all degrees of worth or worthlessness under each or any of them. This is not what I call religion, this profession and assertion; which is only a profession and assertion from the outworks of man, from the mere argumentative region of him, if even so deep as that. But the thing a man does practically believe (and this is often enough without asserting it even to himself, much less to the others); the thing a man does practically lay to heart, and know for certain, concerning his vital relations to this mysterious Universe, and his duty and destiny there, that is in all cases the primary thing for him, and creatively determines all the rest. ${ }^{9}$

One might be tempted to think that it is only accidental analogy, but there are many other places where Carlyle emphasizes the close relationship between belief and conduct. The "convictions" described by Carlyle in the previous paragraph are not to be confined to a private mental event, in a solipsist approach of mind; rather, they are to be expressed in a conduct: there is no real conviction until you act. To speak like Fichte, quoted in the last text of this section, 'Doubt of any sort cannot be removed except by Action. ${ }^{10}$ We have here clearly the conjunction of a theoretical skepticism - about "Speculation" - and of what could be called a "practical activism." One might fancy that such an attitude is only a refinement of speculative skepticism. The action in question is only a sheer effect of the strength of our beliefs, and does not cast light on their contents in any way.

\section{Dewey's Basic Argument: "handle with care"}

13 So far we saw two different responses to skepticism: one focusing on wrong ideas about knowledge, the other focusing on the major difference between professed beliefs and real and active beliefs. As regards Dewey, one can find his own approach in many texts, but for our concerns the clearest version of his argument is not buried very far into The Quest for Certainty, it is addressed in the first lecture, when he explains the title of the book:

European Journal of Pragmatism and American Philosophy, V-2 | 2013 
The quest for certainty is a quest for a peace which is assured, an object which is unqualified by risk and the shadow of fear which action casts. For it is not uncertainty per se which men dislike, but the fact that uncertainty involves us in a peril of evils. ${ }^{11}$

14 We (ourselves and not only the mythological ancestors depicted in Dewey's historical narrative) live in the long shadow of our actions, and this is a fearsome one:

The distinctive character of practical activity, one which is so inherent that it cannot be eliminated, is the uncertainty which attends it. ${ }^{12}$

This practical insecurity is the main cause of our attempts at theoretical certainty: "Insecurity generates the quest for certainty." ${ }^{13}$ The whole series of lectures deals with the way we can do something about this insecurity of action, which is the primary problem, and, as a result, with the way we can dismiss the need for theoretical certainty that was a wrong response to it. One has to address the former problem, about the control of action, if one wants to get rid of the latter. One can see why the problem is different from that faced by both Peirce and James; here wrong expectations about knowledge derive from the uncertainty of action (as in Peirce); action is not the solution, it is the problem (as in James).

It might also be the case that the crude opposition between pragmatism and skepticism should be qualified: Olivier Tinland, in his piece on "Skepticism, Irony and Cultural Politics in Rorty's Philosophy," claims that "beyond the simplistic opposition between anti-skepticism (including classical pragmatism) and skepticism, it is necessary to make place for a pragmatic skepsis which constitutes the social practice of philosophy, i.e. the understanding of the permanent shifts of the vocabularies we use to describe our culture."

\section{Social Dimensions of Doubt: Causes and Consequences}

17 In addition to providing a rebuttal of the "paper-doubts" of the would-be skeptic, pragmatists have also been quite responsive to the social dimensions of doubt. This is the true concerning of the causes of doubt: Peirce, when he claims that we cannot doubt at will and that paper-doubts do not count as actual doubts, repeatedly urges that one of the strongest springs of doubt is to be found in the doubts of other competent inquirers: “ Whatever is doubted by men whom there is reason to think as competent judges, is so far doubtful; and, therefore, a certain shade of doubt will hang over almost all psychological or very general propositions." 14 Assessing whether this is a mere psychological remark or if that involves more structural aspects of inquiry is an open question, ${ }^{15}$ but here doubt is clearly depicted as a socially motivated phenomenon. This is true also regarding consequences: doubt has consequences on epistemic trust; on the way we discuss truths, either about the sciences or about the "construction of the good." Readers of Dewey's Quest and of some of his most important political writings can easily see how practical uncertainty can degenerate into practical and political skepticism, preventing the emergence of public and of publics in the plural. This social aspect of the question has received less attention, perhaps, than the general pragmatist stance towards skepticism, and the present symposium offers a first round of insights into this aspect of the question: the papers retrieved below all cast light on important aspects of the debate, on justification, on scientific dogmatism, on irony and skepticism, on doubt and legal theory, on skepticism 
and political anarchism. Such would be the shortest route to introduce to the following selection of papers.

But another and longer route can be taken to give more flesh to the core problem, the idea being to show that a pragmatist approach to inquiry is bound to face the problems raised by the social articulation of doubt, for at least two series of reasons. These two sets can be read as a further introduction to the papers below and as sketching the framework for further inquiries.

\section{Agnotological Challenges}

Firstly, strategic and sometimes artificial doubts about the sciences - about scientific certainty, scientific consensus and scientific normativity - have played a prominent role in public debates recently, whether over Evolution (in some countries), over the carcinogenicity of Tobacco Smoke, over Global Warming, acid rains, lead, pollutants, Bisphenol... Accordingly, these kinds of artificial doubts have met a growing attention, insofar as they have increasingly been enrolled by "doubt-mongers" to forge controversies. This set of questions is crucial in a recent style in history of science dubbed "Agnotology"(aka: the science of ignorance ${ }^{16}$ ), which focuses on the "cultural production of ignorance." 17

This might seem far removed from Peirce's theory of inquiry and from Dewey's notion of the public and related problems. In point of fact, the so-called agnotological literature raises questions that are pivotal for pragmatists. An oft-quoted internal memo from a Tobacco PR, retrieved in the Tobacco Documents, subpoenaed in the 1980s, will help understanding why:

Doubt is our product since it is the best means of competing with the "body of fact" that exists in the mind of the general public. It is also the means of establishing a controversy. ${ }^{18}$

Doubt-mongers of this kind perfectly understand that doubt is what stands between us and our conclusions (Tobacco smoke causes cancer), and sometimes our actions (quitting, regulating Tobacco Smoke, for example): as long as we doubt, a stable consensus and a political regulatory agenda will not be in order. It is thus a genuine question to know whether this kind of doubts can be faced with the same weapons as the more classical skeptical modes and with pragmatist tools for that matter. Doubt-mongers also perfectly understand that inquiries are practical matters: they are things we do, and they are also things we can derail. Doubt-mongers, finally, are fully aware that the kind of doubt they promote is a socially distributed phenomenon: they don't want us to question our own dogmatic bent, as the classical skeptic would do, they want to make certainties and consensus reached by $\mathrm{B}$ dubious for $\mathrm{C}$. The extent of the challenges raised by agnotological processes might be overlooked, for several reasons:

(1) Their extension is wide: the "cultural production of ignorance," in Robert N. Proctor's words, certainly covers sundry processes that might differ dramatically (and pragmatically indeed) in their operation: how facts travel (or don't) between metropolis and colonies (Howlett and Morgan, 2011), health hazards of basic nutrients (Taubes, 2011), our knowledge and non-knowledge about pollutants (Markowitz and Rosner, 2002), lies of the industry, espionage and counter-measures, and all the studies gathered under the loose rubric of agnotology often correspond to different logics and patterns. Proctor 
has focused on the war against cancer and after that on the strategies of the tobacco industry; Michaels on pollutants and toxic products, Galison on secrecy and its consequences on normal epistemology, Oreskes and Conway on climate-skepticism. Still, they all concern perturbations of normal inquiries.

(2) Secondly, some readers, inspired by Rorty perhaps, might hold that epistemology is a thing of the past, and that debunking fake or specious controversies presupposes that we can have a definition or at least criteria of genuine knowledge or of good science. Does this mean that a pragmatist approach would be displaced here? It is hardly the case, even for staunch Rortians: Rorty's main target was with the attempts at "founding" epistemology and maybe less with the ordinary claims of knowledge, including scientific knowledge. Frega claims, in his introduction to Pragmatist Epistemologies, that " Epistemology has always been and still remains a central concern for pragmatism" (Frega, 2011: 3), and this is certainly true before and after Rorty. Another argument deserves consideration: one cannot hold consistently that thought and knowledge are not (only) "in our heads" (e.g. in the heads or brains of single individuals), as Peirce, Dewey, Mead and later Putnam would have it, without holding that we should certainly be interested in what "happens" to knowledge, in particular to our ideas about inquiry, in public debates and disputes, in education, in scientific policies which bear on the long term structure of knowledge. In the still ongoing debate between Lippmann and Dewey about the possibility for the public to be more than a brute force supporting this or that policy, the idea of a "civic epistemology" or of "science literacy" are still hotly debated issues. ${ }^{19}$

(3) Thirdly, this corpus, if one did stop at the titles, could make us think that we just have a new "conspiracy theory" on the market, except that its main topic would not be government lies anymore, but storytelling from polluters. Merchants of doubt (Oreskes \& Conway, 2010), Doubt is their product (Michaels, 2008), Deceit and Denial (Markowitz \& Rosner, 2002), Bending Science (McGarity \& Wagner, 2008), or in French La Fabrique du mensonge (Foucart, 2013) have titles that might comfort us into thinking that even the most ordinary procedures become the sign of darker and scarier events, as in paranoid narratives. ${ }^{20}$ Funding neuroscience on the chemistry of pleasure becomes the symptom of a fog science aiming at proving the benefits of nicotine; a single occurrence becomes the symptom of a concerted and distributed action, the springs of which are shared only by a small group. Focusing on strategies of distortion of information does not necessarily imply that one does subscribe to a general, big through-and-through narrative. On the contrary, debunking agnotological attempts as circumscribed and local operations - that we can describe in a naturalist and empiricist account of inquiry - certainly is a great antidote to "paranoid style" narratives. We have an epistemology, we need an antiepistemology, to use Galison's words: “Epistemology asks how knowledge can be uncovered and secured. Anti-epistemology asks how knowledge can be covered and obscured." ${ }^{21}$ Both belong to a pragmatist outlook, which is incomplete if there is no account of anti-epistemology.

Can pragmatism offer, for example, an account of reasonable doubt in the sciences that would dismiss pathological doubts about the sciences, in the same way as the classical pragmatists have dismissed Cartesian unreasonable doubts? Agnotological processes raise a classical skeptical challenge, related to indiscernibility: what are the required materials in order to make sense of the difference between doing science and talking science, between inquiries and make-believe inquiries, between actual controversies and "Teach the controversy" mottoes? That is a genuine challenge and pragmatist accounts, being 
responsive to the practical background of inquiry, are certainly better equipped than other epistemologies to face it.

There is still a gap in the literature on this, and conceptual clarifications on the notions of authority, dogmatism and scientific norms that are omnipresent in the controversies we have been referring to, will be highly precious. In this symposium, Marletta's paper, drawing on Kuhn and Wittgenstein in a pragmatist perspective, casts new light on the idea of scientific dogmatism and authority and is very helpful in this preliminary task, sketching a concept of "social dogmatism" ("blind (uncritical) adherence of a community to the "formal" system of norms and conventions, which constitutes its practice"), which leads the author to providing his own solution to the problem we have just raised, by showing that in a scientific context, "the distinction between meaningful doubt (which is positive for scientific progress) and pathological doubt (which turns into scepticism) is clear only from a social point of view about the nature of science and the organisation of scientific communities."

\section{Political and Ethical Dimensions of Doubt}

Secondly, the emergence of a new kind of pragmatism, inspired by Sellars and focusing on the social articulation of the space of reasons, had prompted new developments and sometimes a reconstruction of the main notions of classical epistemology: it is now more natural to think of doxastic states in terms of endorsements, acknowledgments and entitlements. Brandom, in Making It Explicit (1994), has claimed that his inferential approach helped dispensing with the ambiguities of the notions of belief and doubt. ${ }^{22}$ It might also be the case that a more classical pragmatism allows for such a style of inquiry. I will build here on Dewey to sketch the ethical and political dimensions of doubt, which will lead me a bit deeper in the texts, but for the sake of a general argument: some doubts have social consequences, insofar as they threaten, because of systematic conceptual mistakes, the very existence of ethical and political communities; one might also have to make room for a kind of deeper doubt, a doubt in front of the possibility of our social existence.

Dewey's Quest focuses on the links between theoretical uncertainty, which prompts for absolutist strategies and is in return a well-known cause of skepticism, and practical uncertainty, the kind of uncertainty that factors in every one of our acts: uncertainty about the issue, uncertainty about the meanings they convey, uncertainty about the values they help enforcing. There is a well-known, and maybe worn-out, aspect in Dewey's argument, and another, maybe more original, one in his treatment of practical uncertainty.

On a first level, we can cast some light on one flavor of skepticism, and maybe on the practical roots of theoretical skepticism: according to Dewey, most of our systematic attempts, in the sphere of knowledge, would be induced by the fear of the consequences of our actions. The theoretical quest for certainty would be a side effect of the practical quest for safety or security. Man would seek relief in the theoretical part of his life, by building closed and consistent systems, looking for what James called "moral holidays." Philosophical systems would be our ways of conjuring the sharp angles of the world. This first level is interesting in its own right, but it is well in line with what one expects generally from pragmatism, even on a first reading. But there is also a second level where the main question is not that of the cause or of the reason of our theoretical skepticism, 
or even of our attempts at theoretical certainty, but that of defining what is uncertain about our actions, about our practice: their consequences? The meanings they are apt to convey? Their limits: where do our actions stop, in which way are they ours? Values are certainly paradigmatic of this kind of uncertainty.

A major source of skepticism about values lies with the idea that practice would involve merely individual or private gratifications, leading to extreme pluralisms and relativisms. I will not get into the details of pluralistic challenges here: Matt Sleat, in his paper on "Justification, Pluralism and Pragmatism: The Problems and Possibilities of a Peircian Epistemic Justification of Liberalism" has a very detailed discussion of the problems faced by epistemic justifications of liberalism in the context of pluralism, and also a strong (and challenging) claim about the way Peirce, contra Misak, might be used to resist artificial doubts about liberal institutions ("this would translate into the thought that I only have reason to justify my belief that liberal institutions are the best or right way to regulate modern societies if I have reason to doubt that all humans are free and equal and are to be treated as such, the moral belief central to the concept of being reasonable"). I will stick here with the kind of "Value-Skepticism" that emerges when doubt is cast on the very idea that our joint acts and communal endeavors are the only places anyway where values can have their own stability and sustainability, and Dewey thinks that it is unavoidable when one has a narrow account of practice. As he puts it, the scope of action "cannot be restricted to self-seeking acts, nor to those of a prudential aspect, nor in general to things of expediency and what are often termed 'utilitarian' affairs." The first obstacle is thus our narrow conception of practice and the wrong idea that our values cannot have the same fragility as our actions. The narrow version of practice is another way to take unlimited "moral holidays" since what will happen is not "up to us." On the contrary, says Dewey, "The maintenance and diffusion of intellectual values, of moral excellencies, the aesthetically admirable, as well as the maintenance of order and decorum in human relations are dependent upon what men do." Once we see that there is not a distinct realm of being where our values live and another, crasser, where we have our actions, "We should regard practice - concludes Dewey - as the only means (other than accident) by which whatever is judged to be honorable, admirable, approvable can be kept in concrete experienceable existence." The (conceptually) narrow account of practice has skeptical consequences.

How can we understand, then, the sustainability of values? The tenth chapter of Quest, "The Construction of Good," is well known in its main lines; the idea is that the sustainability of values is a joint, a communal work. Dewey gives there his own answer to the narrow account of practice and its skeptical consequences. He faces a wrong idea, the idea that we would have to choose between a world of eternal and fixed values (something that would always be here beforehand; something that will clash with the fallibility and experimental nature of our knowledge of nature), on the one hand, and mere "enjoyments such as actually obtain," ${ }^{23}$ temporary and even superficial pleasures, on the other hand. If it is something we don't enjoy, we don't care for, this is certainly not a value (you have, in a certain way, to crave for it); if it is something that is only satisfying and not satisfactory, this is certainly not a value, but the possibility of a value, awaiting further inquiry. ${ }^{24} \mathrm{~A}$ value is "whatever is taken to have the rightful authority in the direction of conduct." ${ }^{25}$ This has to be experimented and revised. It is not confined in the mere instant, neither is it severed from the things we enjoy. Dewey thinks accordingly we can define "value by enjoyments which are the consequences of intelligent action."26 
What is at stake here is not how we've been together, not actualities, but what kind of shared pleasures we can aim at. Now, one cannot tell in advance what will count as a value: "Experimental empiricism in the field of ideas of good and bad is demanded to meet the conditions of the present situation." ${ }^{27}$ There is a kind of practical uncertainty, here, that can turn into practical skepticism - or not.

A value is thus not something that satisfies but something that is satisfactory and Dewey points an important conceptual difference between the two; missing the difference is missing the difference between the narrow account of practice and the larger one he tries to articulate. To tell the satisfying from the satisfactory, the enjoyed from the enjoyable, as Dewey tries to do, ${ }^{28}$ is to point the difference between an actuality, an event, and something that presents a normative and social articulation; you cannot describe a value without getting involved at least into a narrative about the social setting, into a bet about the way we would live in such a setting: "To declare something satisfactory is to assert that it meets specifiable conditions. It is, in effect, a judgment that the thing 'will do'. It involves a prediction; it contemplates a future in which the thing will continue to serve; it will do. It asserts a consequence the thing will actively institute; it will do."

In order to know what we would enjoy, we have to know more about the conditions of our actual enjoyments, we won't be able to dismiss the experimental method. If we want to understand this idea, there is an interesting parallel, useful to understand the difference between feeling a private pleasure and holding to a value in the following pages: one can point nearly the same difference between what has been eaten and what is edible; to know if something has been eaten is to be able to report a fact (maybe we can think of forensics in CSI), to know if something is edible is possible only "when we have a knowledge of its interactions with other things sufficient to enable us to foresee its probable effects when it is taken into the organism and produces effects there." ${ }^{29}$ Maybe we'll need all the science we have at hand (is a GMO taco shell edible?), we'll need rules, knowledge about other activities (is it safe to eat such a big cake before running a marathon?).

Holding to a value, to what would be a sustainable enjoyment to us, in the future, is in the same way impossible without a projection of the conditions that would secure this enjoyment, of what would be our stance, our attitudes, our perspectives; it is impossible without a prefiguration of a community "unattained but attainable," to take Cavell's phrase. That would be the optimistic part of Dewey's project: the "good" is something we are responsible for; we have to be experimentalists in the way in beliefs about values in the same way as we have to be experimentalists about the structure of things if we don't want to face theoretical and practical skepticism at every corner.

But here opens another - gloomier - echo of Cavell's lines about Stuart Mill here; in On Liberty, Mill remarks that people do not dare to ask the only question that would make utilitarianism possible: what would make me happy? Is it the state of Society that I desire? ? $^{30}$ Oddly enough, Dewey asks nearly the same question: how is it that we are so scrupulous about the formation of our ideas of natural objects and that we so completely neglect to think about what we hold to? "In fact, the most profound lack is not the will to act upon goods already known but the will to know what they are." ${ }^{31}$ At this very point that we move briefly from something that is a fallibilism about values (we have to experiment, we don't have a definitive answer, any one of them can be ill-grounded or deceptive), which is not a skepticism, to the perspective that, maybe, we will not ask the question about what we care for, about what we hold to, which definitely is a kind of practical skepticism. The emergence of publics (and the same case could be made about the 
Individual), in the nearly contemporary The Public and its problems, is something that is not guaranteed and that Dewey says clearly in that text that we can we can permanently be diverted from their emergence.

There is a "curable" uncertainty of practice that can turn into a radical one concerning the present dispensation of our culture, if the latter prevents us from asking the very question about the good that Dewey and his perfectionist colleagues are asking. Fiala's paper, in the present symposium, brings this question further, arguing that "the anarchist strain in American pragmatism is linked to skepticism about the justification of large social institutions," which leads him to explore the connections between anarchism, skepticism, Emerson, Thoreau, Addams and Dewey, also to inquire about the possibility of "Pragmatic meliorism" as aiming "at incrementally improving the world, not at radically revolutionizing it based upon some utopian ideal." But there are also two other layers of uncertainty that can combine with this one; one that is radical and that is characteristic of any situation, one that is pervasive and is linked with the way law always lags behind social change. Both involve a particular social texture, as we'll see.

\section{5. "As a matter of fact, men do not begin thinking with premises"}

Practical uncertainty comes twofold at the very least: it is both an irreducible component of each situation, something that "happens" to us, but it is also something that can be made worse by the present dispensation of our institutions, something that we can make with our own hands so to speak. In both cases, the social setting and the social articulation of doubt are a key element.

To give some flesh to that idea, we can refer to an earlier text by Dewey, "Logical Method and Law," published in The Philosophical Review in 1924, five years before Quest. ${ }^{32}$ Dewey articulates his own view of logic with the type of logic that is involved in legal reasoning; it is interesting also, as far as the history of legal pragmatism is involved, since, as he will also do in Experience and Nature, Dewey comments upon Oliver Wendell Holmes, one of the members of the Metaphysical Club. Dewey gives his definition of logic first (this is nearly 15 years before the big Logic), after the distinction he draws between routine actions and actions founded on principles or reasons:

I define logical theory as an account of the procedures followed in reaching decisions of the second type [not routine or "hunch," but actions based on reasons], in those cases in which subsequent experience show that they were the best which could have been used under the conditions. ${ }^{33}$

There is an obvious parallelism between this vision of logic and the kind of reasoning used in law: according to Wendell Holmes, the whole point in Law lies not in a rational construction of (antecedent) norms and rules but in a kind of prediction upon what judges will do in point of fact. Holmes and Dewey are thus on a par when it comes to debunking spurious certainties. Holmes is criticizing, in the domain of law, exactly the wrong kind of logic that Dewey contrasts with his own experimental logic. Pragmatists do not claim that we can hold whatever belief we wish as long as we are satisfied with it, they say in general that this kind of satisfaction, if it is a feeling of ease and security, has nothing to do with what is actually at stake if it's not revised incessantly in the course of inquiry. ${ }^{34}$

Experience shows that the relative fixity of concepts afford men with a specious sense of protection, of assurance against the troublesome flux of events. Thus 
Justice Holmes says: "The language of judicial decisions is mainly the language of logic. And the logical method and form flatter that longing for certainty and repose which is in every human mind. But certainty is generally an illusion." From the view of logical method here set forth, however, the undoubted facts which Justice Holmes has in mind do not concern logic, but rather certain tendencies of the human creatures whose use logic, tendencies which a sound logic will guard against. For they spring from the momentum of habit once formed, and express the effect of habit upon our feelings of ease and stability, feelings which have little to do with the actual facts of the case. ${ }^{35}$

Dewey then offers two claims that are interesting for the present purpose: firstly, the idea that in law as in logic, premises come at the end of inquiry. In any situation (practical situation would be a pleonasm), there is an uncertainty more fundamental than that of the issue and of the consequences that played such an important role in Quest; it is the uncertainty pertaining to the identification of the case. Dewey, while he acknowledges that there are important differences between judgment in logic and argumentation in the context of the Law, thinks that the lawyer's type of reasoning has something to do with the particular kind of experimental logic he himself tries to articulate: the point that is the most important to discuss in court concerns what the defendant was actually doing, and what premises he was following:

Thinking actually sets out from a more or less confused situation, which is vague and ambiguous with respect to the conclusion it indicate, and that the formation of both major premiss and minor proceeds tentatively and correlatively in the course of analysis of this situation and of prior rules. As soon as acceptable premisses are given - and of course the judge and jury have eventually to do with their becoming accepted - the conclusion is also given. In strict logic, the conclusion does not follow from premisses; conclusions and premisses are two ways of stating the same thing. Thinking may be defined either as the development of premisses or development of a conclusion; as far as it is one operation it is the other. (ED: 359).

41 What was Scopes, from the Monkey trial in 1925, doing when he was teaching evolution to his students: violating the Butler Act, teaching students the truth, only using the biology textbook, Maher's Civic biology, that was available in Tennessee as in other States? What is Nora doing when she leaves her dull husband in Ibsen's A Doll's House? There is a preliminary analysis, which is most of the times undecided in advance, and which plays a fatal role. Once the premisses are agreed upon, most of what we'll have to say about the act is already well decided.

If we pay attention to the very words Dewey uses, the premises are not chosen arbitrarily, they are agreed upon by the judge and the jury (we can have a voice in telling what our fellow-men are actually doing), it is tempting to think that he's explaining in which ways we make ourselves intelligible to ourselves, and to others, and that he might also be thinking of the concrete cases where this clarification obtains through a conversation, a collective deliberation. Living in the space of reasons, to use Sellars's phrase, does not occur without the powerful incentive of others asking us for reasons, and keeping asking for them until they got them, raising doubts we have to answer, and this is certainly why, in this very text, Dewey "out-Sellars" Sellars himself so to speak, by claiming that sharing these kind of doubts and reducing this uncertainty clearly belongs to the game of "accounting for [one's] decisions to others who demand a reason":

It is quite conceivable that if no one had ever had to account to others for his decisions, logical operations would never had developed, but men would use exclusively methods of inarticulate intuition and impression, feeling; so that only after considerable experience in accounting for their decisions to others who 
demanded a reason, or exculpation, and were not satisfied till they got it, did men begin to give an account of themselves in the process of reaching a conclusion in a justified way. ${ }^{36}$

Doubts and queries, which are not only public but also distributed, in a word, social, might be crucial in the development of logical operations. F. Kellogg's paper, in the present symposium, deals with a germane question, at a fundamental level, showing how nineteenth-century references to the syllogism by J. S. Mill and Oliver Wendell Holmes Jr. "reveal a distinct approach to the logic of inference in the formative years of pragmatism," showing also how uncertainty is accommodated and how generals emerge both in Law and Science.

Dewey also defends the idea that Law helps conferring regularity to our practices (and as such reduces actual practical uncertainty) but can also be a potent cause of political and social insecurity. Judges have to explain their decisions; they have to give reasons and refer to principles or jurisprudence; they have also (or the legislator has) to write laws. We are not totally lost in our dealings with others since the Law introduces a fair amount of regularity in the behaviors. They become predictable, or at least more predictable. The "antecedent" assurance is great where conditions are uniform, much less where invention is active, when "new devices in business and communication bring about new forms of human relationship." ${ }^{37}$

Hence to claim that old forms are ready at hand to cover every case that may be applied by formal syllogizing, is to pretend to a certainty and regularity which cannot exist in fact. The effect of the pretension is to increase practical uncertainty and social instability. Just because circumstances are really novel and not covered by old rule, it is a gamble which old rule will be declared regulative of a particular case, so that shrewd and enterprising men are encouraged to sail close to the wind and trust to ingenious lawyers to find some rule under which they can get off scot free. $^{38}$

Too much rigidity in our laws cause social uncertainty, but that would also be true for ever-changing laws, and in both cases they can contribute to the kind of practical uncertainty that was described at the beginning of this essay.

From all these standpoints, epistemological, ethical, political, it is our hope that the present symposium gives food for thought and that, even if of course further developments are needed, and if many other pragmatist references might have been included, the centrality of the questions raised by the social texture of doubt will be a bit more visible after this symposium.

\section{BIBLIOGRAPHY}

BRANDOM R., (1994), Making It Explicit: Reasoning, Representing, and Discursive Commitment, Cambridge (Mass.), Harvard University Press.

CARLYLE T., (1838), Memoirs of the Life of Scott, Westminster Review, Jan. 1838, 293-345.

CARLYLE T., (1974), On Heroes and Hero Worship, London, Oxford University Press [1841]. 
CAVELl S., (2004), Cities of Words, Cambridge (Mass.), Harvard University Press.

COOKE E., (2006), Peirce's Pragmatic Theory of Inquiry: Fallibilism and Indeterminacy, NY, Continuum International Publishing Group.

DEWEY J., (LW4), The Quest for Certainty, in The Later Works of J. Dewey, 1925-1953, Boydston J. A. ed., Southern Illinois University Press, Carbondale and Edwardsville, 1981-1990.

DEWEY J., (ED1), The Essential Dewey, Volume 1, Hickman L. A. \& Alexander Th. M. (eds.), Indianapolis, Indiana University Press.

FISCH M. H., (1942), “Justice Holmes, the Prediction Theory of Law, and Pragmatism," Journal of Philosophy 39, 85-96.

FOUCART S., (2010), Le populisme climatique, Paris, Denoël.

FOUCART S., (2011), “L'ignorance : des recettes pour la produire, l'entretenir, la diffuser," Le Monde , samedi 4 juin 2011, 16.

FOUCART S., (2013), La fabrique du mensonge: comment les industriels manipulent la science et nous mettent en danger, Paris, Éditions Denoël.

FREGA R. (ed.), (2011), Pragmatist Epistemologies, Lanhan, Lexington Books.

GALISON P., (2008), "Removing Knowledge: The Logic of Modern Censorship," in Agnotology: The Making and Unmaking of Ignorance, 37-54.

GUNNARSSON L., (2010), "The Philosopher as Pathogenic Agent, Patient, and Therapist: The Case of William James," Royal Institute of Philosophy Supplement 66, 165-86.

HAACK S., (1982), “Descartes, Peirce and the Cognitive Community,” Monist 65, 156-81.

HAACK S., (2005), "Trial and Error: The Supreme Court's Philosophy of Science," American Journal of Public Health 95 (S1), S66, 2005.

HOFSTADTER R., (1964), “The Paranoid Style in American Politics,” Harper's Magazine 229 (1374), 77-86.

Hоoкway C., (2012), The Pragmatic Maxim: Essays on Peirce and Pragmatism, Oxford, Oxford University Press.

HоoKWAY C., (1999), "Modest Transcendental Arguments and Sceptical Doubts: A Rely to Stroud," in Stern R. (ed.), Transcendental Arguments: Problems and Prospects, Oxford, Clarendon Press, Mind Occasional Series, 173-88.

HOWLETT P. \& M. MORGAN, (2011), How Well do Facts Travel? The Dissemination of Reliable Knowledge, Cambridge, Cambridge University Press.

JAMEs W., (1979), The Will to Believe and other Essays in Popular Philosophy, Cambridge (Mass.), Harvard University Press.

KRIMSKY K., (2003), Science in the Private Interest: Has the Lure of Profits Corrupted Biomedical Research? , Lanham, Rowman and Littlefield Publishers.

LATOUR B., (2004), "Why has Critique Run out of Steam? From Matters of Fact to Matters of Concern," Critical Inquiry 30 (2), 225-48.

LIPPMANN W. \& B. LATOUR, (2008), Le public fantôme, Paris, Demopolis.

MAcGilvRay E., (2013), “Democratic Doubts: Pragmatism and the Epistemic Defense of Democracy,” Journal of Political Philosophy, published online July 2013. 
MARKoWITZ G. \& D. ROSNER, (2002), Deceit and Denial: The Deadly Politics of Industrial Pollution, Berkeley, University of California Press.

MCGARITY T. \& W. WAGNER, (2008), Bending Science: How Special Interests Corrupt Public Health Research , Cambridge (Mass.), Harvard University Press.

MICHAELS D. \& MONFORTON C., (2005), "Manufacturing Uncertainty: Contested Science and the Protection of the Public's Health and Environment," American Journal of Public Health 95 (S1), S39S48.

MICHAELS D., (2008), Doubt is their Product: How Industry's Assault on Science Threatens your Health, Oxford, Oxford University Press.

MENDELl M., (1994), "Dewey and the Logic of Legal Reasoning," Transactions of the Charles S. Peirce Society 30, 3, 575-635.

MILL J. S., (1963-1991), Collected Works of John Stuart Mill, Robson J. S. ed., Toronto, University of Toronto Press.

MISAK C. J., (1991), Truth and the End of Inquiry a Peircean Account of Truth, Oxford, Oxford University Press.

ORESKES N. \& E. M. CONWAY, (2010), Merchants of Doubt: How a Handful of Scientists Obscured the Truth on Issues from Tobacco Smoke to Global Warming, New York, Bloomsbury Press.

PEIRCE C. S., (W), Writings of Charles Sanders Peirce, Indianapolis, Peirce Edition Project.

PRITCHARD D., (2005), “Wittgenstein's on Certainty and Contemporary Anti-scepticism," in MoyalSharrock D. \& Brenner W. H. (eds.), Investigating on Certainty: Essays on Wittgenstein's Last Work, London, Palgrave Macmillan, 189-224.

PROCTOR R. \& SCHIEBINGER L. L., (2008), Agnotology: The Making and Unmaking of Ignorance, Stanford, Stanford University Press.

PROCTOR R., (1991), Value-Free Science? Purity and Power in Modern Knowledge, Cambridge (Mass.), Harvard University Press.

PROCTOR R., (1995), Cancer Wars: How Politics shapes what we know and don't know about Cancer, New York, Basic Books.

PROCTOR R., (2011), Golden Holocaust: Origins of the Cigarette Catastrophe and the Case for Abolition, Berkeley, University of California Press.

RORTY R., (2010), “Comments on Michael Williams' Unnatural Doubts,” Journal of Philosophical Research 22, 1-10.

TIERCELIN C., (2005), Le Doute en question : Parades pragmatistes au défi sceptique, Paris, L'éclat.

STAVO-DEBAUGE J., (2012), Le loup dans la bergerie : Le fondamentalisme chrétien à l'assaut de l'espace public, Geneva, Labor et Fides.

SULLIVAN S. \& TUANA N. eds., (2007), Race and Epistemologies of Ignorance, Albany (NY), State University of New York Press.

TAUBES G., (2011), “Is Sugar toxic?,” NY Times Magazine, Apr. 17.

TENNYSON G. B. ed., (1969/1984), A Carlyle Reader, Cambridge, Cambridge University Press.

WILlIAMS M., (1996), Unnatural Doubts: Epistemological Realism and the Basis of Scepticism, Princeton, Princeton University Press. 
Williams M., (2010), “Descartes' Transformation of the Sceptical Tradition,” in Bett R. (ed.), The Cambridge Companion to Ancient Scepticism, Cambridge, Cambridge University Press.

\section{NOTES}

1. A complete list would have to include most of the accounts of the pragmatist view of inquiry, See, for example, Hookway (2012, ch. 1), McGilvray (2013), Cooke (2006), Tiercelin (2005).

2. Peirce has in mind something that resembles what Michael Williams calls the "Standard Model," see Williams (1996) and for a reductio of the argument, see Williams (2010).

3. For a more refined account, see Haack (1982).

4. Peirce (W2: 524).

5. Mill (1963-1991, XVIII: 233); the reference is to Carlyle (1838: 315).

6. On this mood, see Gunnarson (2010).

7. James (1979: 134).

8. Ibid.

9. Carlyle (1841: 3).

10. "But indeed Conviction, were it never so excellent, is worthless till it convert itself into Conduct. Nay properly Conviction is not possible till then; inasmuch as all Speculation is by nature endless, formless, a vortex amid vortices, only by a felt indubitable certainty of Experience does it find any centre to revolve round, and so fashion itself into a system. Most true is it, as a wise man teaches us, that 'Doubt of any sort cannot be removed except by Action'." Carlyle, Sartor Resartus, Bk II, Ch IX, In Tennyson (1969/1984: 259).

11. LW4: 7.

12. LW4: 6 .

13. LW4: 206.

14. Peirce (W2: 189), see also W2: 314 and W3: 14, emphasis mine.

15. See Misak (1991: 58).

16. The idea is introduced in Proctor (1995), and Proctor credits Iain Boal for the term (Proctor \& Schiebinger, 2008: 27). Two conferences were devoted to that idea (at Penn State in 2003 and at Stanford in 2005), the papers being retrieved in Proctor and Schiebinger (2008). See also Michaels (2008), Michaels and Monforton (2005), Oreskes \& Conway (2010), Sullivan \& Tuana (2007), Foucart (2010), Krimsky (2003), Markowitz \& Rosner (2002). A conference was organized at the ZIF of Bielefeld by Martin Carrier in 2011 (see Foucart, 2011), another one, organized by SND, Bielefeld and the PEPS PSL Les sciences, le doute et l'ignorance took place in June 2013 in Paris as well as a Conference at Paris sciences Lettres and ENS in December 2013.

17. See in particular Proctor (1991: 13): "It is not enough to supplement the epistemological question (how do we know?) only by the social contextual question (what are the origins of knowledge?), we must also ask the political, ethical, and activist questions : Why do we know what we know and why don't we know what we don't know? What should we know and what shouldn't we know? How might we know differently?"

18. Brown \& Williamson Archives, Memo Smoking and Health proposal, 1969 [tobaccodocuments.org/bw/332506.html].

19. Lippmann \& Latour (2008).

20. I am of course thinking of Hofstadter (1964).

21. Ibid., in (Proctor \& Schiebinger, 2008: 45).

22. "An unambiguous, univocal technical term 'doxastic commitment' is introduced, which comprises both commitments one is prepared to avow and commitments that follow from those one acknowledges. But attention to the attitudes in terms of which those deontic statuses are 
explained makes it possible also to distinguish clearly between these two kinds of commitment, as 'belief'-talk does not. The proposal is accordingly not to analyze belief in terms of commitment but to discard that concept as insufficiently precise and replace it with clearer talk about different sorts of commitment." (Brandom, 1994: 195-196). On doubt within this perspective, see p. 177 and 209.

23. LW4: 228.

24. Ibid.: 228 .

25. Ibid.: 204.

26. Ibid.: 207.

27. LW4: 206.

28. Ibid.: 208-9.

29. Ibid.: 213 .

30. (Cavell, 2004: 96).

31. LW4: 214.

32. Fisch (1942) has some passing mentions of this paper and stresses the quote on concepts. Mendell (1994) highlights some important aspects of Dewey's legal thought.

33. ED1: 356.

34. For the same argument in Peirce, see Fixation of Belief, W3: 244; and An American Plato, W5: 230.

35. ED1: 357.

36. ED1: 359 .

37. ED1: 360

38. Ibid.: 360

\section{ABSTRACTS}

In addition to providing a rebuttal of the "paper-doubts" of the would-be skeptic, pragmatists have also been quite responsive to the social dimensions of doubt. This is true concerning the causes of doubt. This is true also regarding its consequences: doubt has consequences on epistemic trust; on the way we discuss truths, either about the sciences or about the "construction of good." Readers of Dewey's The Quest for Certainty and of some of his most important political writings can easily see how practical uncertainty can degenerate into practical and political skepticism, preventing the emergence of the public. This social aspect of the question has received less attention, perhaps, than the general pragmatist stance towards skepticism, and the present symposium offers a first round of insights into this aspect of the question: the papers retrieved below all cast light on important aspects of the debate on justification, on scientific dogmatism, on irony and skepticism, on doubt and legal theory, on skepticism and political anarchism.

\section{AUTHOR}

MATHIAS GIREL

USR Cirphles, École normale supérieure - Paris

mathias.girel[at]ens.fr 